University of Nebraska - Lincoln

DigitalCommons@University of Nebraska - Lincoln

USDA National Wildlife Research Center - Staff Publications
U.S. Department of Agriculture: Animal and Plant Health Inspection Service

January 2001

\title{
Non-Target Hazard Assessment of Using DRC-1339 Avicide to Manage Blackbirds in Sunflower
}

John D. Eisemann

USDA/APHIS/WS National Wildlife Research Center, John.D.Eisemann@aphis.usda.gov

George M. Linz

USDA/APHIS/WS National Wildlife Research Center, george.m.linz@aphis.usda.gov

John J. Johnston

APHIS/WS/National Wildlife Research Center, U.S. Department of Agriculture

Follow this and additional works at: https://digitalcommons.unl.edu/icwdm_usdanwrc

Part of the Environmental Sciences Commons

Eisemann, John D.; Linz, George M.; and Johnston, John J., "Non-Target Hazard Assessment of Using DRC-1339 Avicide to Manage Blackbirds in Sunflower" (2001). USDA National Wildlife Research Center Staff Publications. 585.

https://digitalcommons.unl.edu/icwdm_usdanwrc/585

This Article is brought to you for free and open access by the U.S. Department of Agriculture: Animal and Plant Health Inspection Service at DigitalCommons@University of Nebraska - Lincoln. It has been accepted for inclusion in USDA National Wildlife Research Center - Staff Publications by an authorized administrator of DigitalCommons@University of Nebraska - Lincoln. 
Published in Pesticides and Wildlife, edited by John J. Johnston. ACS Symposium Series 771. American Chemical Society, Washington, DC, 2001. 


\title{
Non-Target Hazard Assessment of Using DRC-1339 Avicide to Manage Blackbirds in Sunflower
}

\author{
John D. Eisemann ${ }^{1,3}$, George M. Linz ${ }^{2}$, and John J. Johnston ${ }^{1}$ \\ ${ }^{1}$ APHIS/WS/National Wildlife Research Center, U.S. Department of \\ Agriculture, 4101 LaPorte Avenue, Fort Collins, CO 80521-2154 \\ ${ }^{2}$ National Wildlife Research Center, 2110 Miriam Circle, Suite B, \\ Bismarck, ND 58501
}

\begin{abstract}
Terrestrial hazard assessments were conducted for the spring blackbird baiting program to protect sunflower crops. Risk Assessment methodology proposed by the Ecological Committee on FIFRA Risk Assessment Methods (ECOFRAM) and the method currently used by the U.S. Environmental Protection Agency $\left(\mathrm{LD}_{50} \mathrm{~s} / \mathrm{ft}^{2}\right)$ were compared for their predictive strengths and for the ease of adapting the assessment to site specific conditions. While the ECOFRAM and $L_{50} \mathrm{~s} / \mathrm{ft}^{2}$ methods identified the same groups of organisms as being at risk, the flexibility of the ECOFRAM methodology allowed more latitude in adapting the assessment to unique behaviors of individual species. These risk assessment approaches indicate that blackbird baiting with DRC-1339 presents acute hazards to select nontarget birds like western meadowlarks and mourning doves but few hazards to most mammals or small granivorous birds like sparrows and finches. However, field experiments indicate that the mitigation measures currently employed in the baiting program, minimize the nontarget hazards.
\end{abstract}

Sunflower production in the United States is centered in North Dakota and South Dakota. In 1997, the U.S. sunflower harvest was 1.5 million metric tons (1 million hectares planted) with North Dakota and South Dakota accounting for $57 \%(526,000$ hectares planted) and $28 \%$ (283,000 hectares planted) of the total harvest, respectively ${ }^{1}$.

${ }^{3}$ USDA, National Agricultural Statistics Service.

http://www.nass.usda.gov/nd/cesuna98.htm, search date 9/9/99

http://www.nass.usda.gov/sd/cesuna98.htm, search date 9/9/99

U.S. government work. Published 2001 American Chemical Society 
Ripening sunflower seeds provide a highly desirable forage source for a variety of pests. The primary vertebrate pests to sunflower include the red-winged blackbird (Agelaius phoeniceus), the common grackle (Quiscalus quiscula), and to a lesser extent the yellow-headed blackbird (Xanthocephalus xanthocephalus) $(1,2)$. In recent years, damage attributed to these species was estimated at over $\$ 5$ million per year (3). A variety of techniques have been used to manage avian depredation in sunflower fields, including the use of chemical toxicants. DRC-1339 (3-chloro-p-toluidine hydrochloride) is the only lethal toxicant currently registered in the U.S. for managing blackbird damage in sunflower during both the spring and fall migrations. Blackbird damage occurs in late-summer when the sunflower crop is ripening. Because it is difficult to lure blackbirds away from ripening sunflower heads to rice baits on the ground, the efficacy of late-summer baiting is likely to be limited (4). This paper focuses on the nontarget hazards associated with the spring blackbird management program when naturally occurring food sources may be limited.

Concern has been raised about the impacts of DRC-1339 to other vertebrates, particularly nontarget birds likely to forage on treated bait sites. The purpose of this paper is to conduct nontarget hazard assessments for DRC-1339 using methodology currently employed by the U.S. Environmental Protection Agency (EPA) and new methodology developed by the EPA-sponsored Ecological Committee on FIFRA Risk Assessment Methods (ECOFRAM) (5). We compare the hazard assessments for environmental relevance, and potential for customizing the assessment for site-specific environmental and nontarget species information. Finally, nontarget hazards identified through these assessments are characterized for select species to provide a picture of the potential risk presented by this program.

\section{Environmental Fate and Toxicology of DRC-1339}

The environmental fate and toxicology of DRC-1339 have been throughly reviewed $(6,7)$. Reported half-lives of DRC-1339 range from 1-3 days and are highly dependent upon climatic conditions. The half-life in soil under aerobic conditions is approximately 25 hours. The aquatic photolysis half-life is between 6.5 and 41 hours. DRC-1339 is highly soluble in water but does not hydrolyze. High affinity to soil organic matter explains the low soil mobility of DRC-1339.

The acute toxicity database for DRC-1339 is noteworthy, with 46 North American mammals and 8 African bird species tested for acute oral toxicity. As illustrated in Figure 1, laboratory studies, while not definitive, support the possibility that DRC-1339 exhibits a differential toxicity and mode of action among taxonomic families $(8,9,10$, $11,12,13,14)$. Target species such as blackbirds, grackles, starlings and corvids are highly sensitive, with $\mathrm{LD}_{50}$ in the range of 1 to $10 \mathrm{mg} / \mathrm{kg}$. Doves, galliformes, and some passerine species are also acutely sensitive to DRC-1339 $\left(\mathrm{LD}_{50} \mathrm{~s}<20 \mathrm{mg} / \mathrm{kg}\right)$ Additionally, the only species of owl tested, the common barn owl, (Tyto alba), was found to be sensitive. One species DRC-1339 is nephrotoxic to sensitive species in that it destroys proximal convoluted tubules, resulting in uremia or increased levels of uric acid in the blood. Metabolism studies have shown that as much as $90 \%$ of a dose

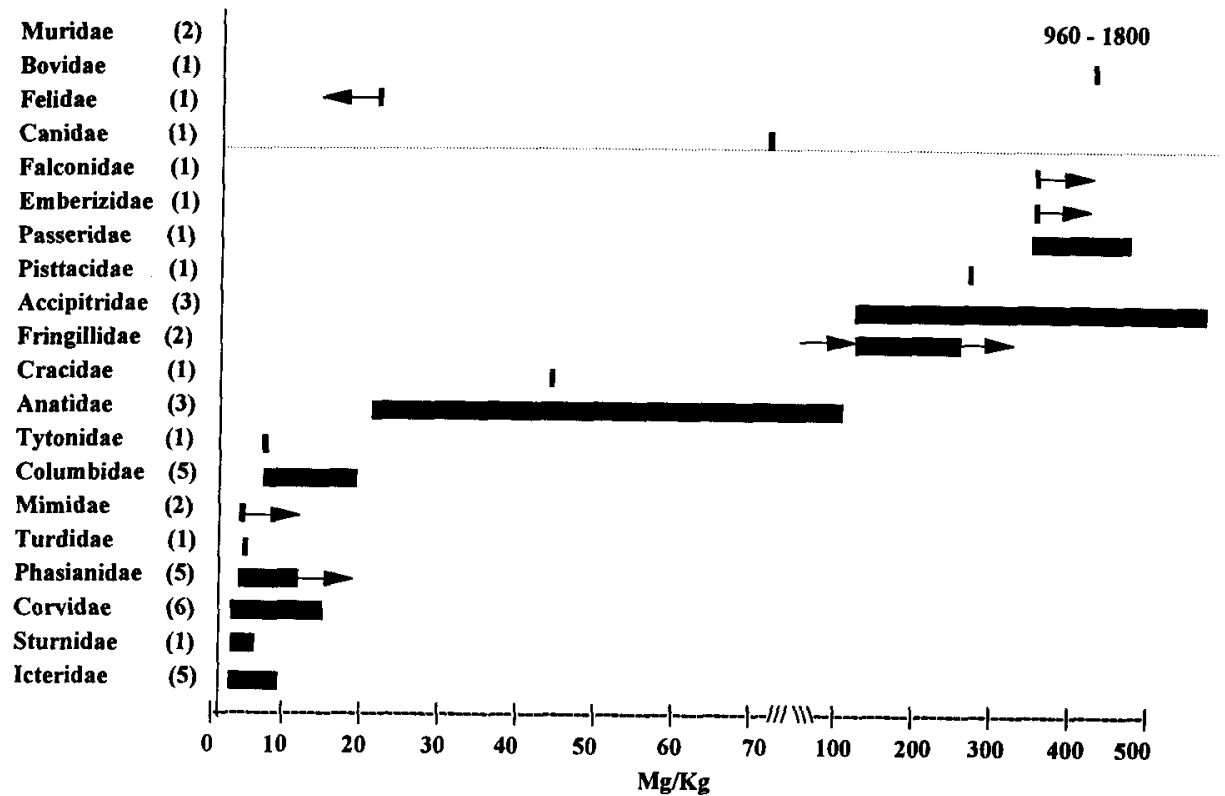

Figure 1. Acute toxicity data for 45 species of North American vertebrates, representing 20 taxonomic families. The range of $L D_{50} s$ for the family Muridae is off the scale at 960 to $180 \mathrm{mg} / \mathrm{kg}$. Arrows represent greater than $(\rightarrow)$ and less than $(\leftrightarrow)$. Numbers in parenthesis are the numbers of species tested in each taxonomic group. The dotted line divides the data for mammals and birds.

administered to birds is excreted in the form of parent com pound or metabolite within 30 minutes $(15,16,17,18)$. Sparrows, finches, raptors and most mammals appear to be relatively insensitive to $\mathrm{DRC}-1339$, with $\mathrm{LD}_{50}$ s greater than $100 \mathrm{mg} / \mathrm{kg}$. Mammals and possibly non-sensitive avian species do not exhibit kidney necrosis, excrete acetylated metabolites in the urine, or show increased levels of methemoglobin in the blood. Nonsensitive animals probably succumb to CNS depression and respiratory failure $(19,20$, $21,22)$.

\section{DRC-1339 Use Practices}

DRC-1339- treated brown rice is formulated at a concentration of $2 \%$ and diluted with untreated rice the day of application at a ratio of $1: 25$. This mixture is broadcast in swathes 6.5 to $17 \mathrm{~m}$ wide with a seed-spreader mounted on an all-terrain vehicle at a rate of 12 to $23 \mathrm{~kg} / \mathrm{ha}$. Treated plots are about $0.8 \mathrm{ha}$ and are located near roads under roostto-field flight paths. Plots are pre-baited with untreated rice for a period sufficient to habituate foraging blackbirds to bait sites and monitor nontarget activity. Up to 4 
subsequent applications can be made after $75 \%$ of the previous application has been consumed or $10 \mathrm{~mm}$ of precipitation has fallen (EPA Registration Numbers. 56228-30, and SD-980005). Decoy birds, housed at the bait site in large cages, are used to draw larger numbers of blackbirds to bait sites.

\section{Methods}

\section{Current EPA Methodology}

The first assessment method follows the current standard used by the U.S. EPA to assess the risk of granular and bait pesticide products, $\mathrm{LD}_{50} \mathrm{~s} / \mathrm{ft}^{2}(23)$. This method relates the amount of pesticide in a given area of field to the $\mathrm{LD}_{50}$ of the most sensitive species or species of interest. The resulting risk quotient (RQ) is compared to the following established Levels of Concern (LOCs):

\begin{tabular}{|c|c|}
\hline If the Acute RQ is: & Presumption \\
\hline 0.5 & Acute high risk to all species \\
\hline 0.2 & Risk that may be mitigated through restricted use \\
\hline 0.1 & Acute risk to endangered species \\
\hline
\end{tabular}

The RQ $\left(\mathrm{LD}_{50} \mathrm{~s} / \mathrm{ft}^{2}\right)$ is calculated by the following equation where $\mathrm{mg}$ ai $/ \mathrm{ft}^{2}=(\mathrm{lb}$ ai/acre $(453,590 \mathrm{mg} / \mathrm{lb}) \div 43560 \mathrm{ft}^{2} / \mathrm{acre}$.

$$
R Q=m g \text { ai/ft } t^{2} \div\left(L D_{s 0}\right)(\text { Body weight in } \mathrm{kg})
$$

\section{ECOFRAM Methodology}

Screening Level Assessment

Hazard assessment procedures also were conducted following methods outlined by the ECOFRAM workgroup. In the ECOFRAM draft document, exposure assessment focuses on a dietary dose equation modified from that proposed by Pastorok et al. (24). The proposed exposure equation allows the determination of total dose by providing a means for summing the total pesticide intake for each contaminated food item and allowing for behaviors unique to individual species (Table I). In the screening assessment, we assumed that $100 \%$ of an animal's daily diet consists of brown rice obtained at the bait site and the entire daily food requirement was consumed at one time. Additionally, Avoidance (AV), Percent of Time in the treated field (PT) and Fresh/Dry Ratio (FDR) are assumed to have no impact and have been eliminated from the equation.

The basic screening assessment using the dietary dose equation is generic in that standard avian and mammalian body weights and food intake rates are used in place of species-specific data. The toxicity reference value, which serves as the denominator of the risk quotient calculation, is the concentration considered hazardous to only five
Table I. Dietary dose equation as proposed by the U.S. EPA ECOFRAM workgroup

\begin{tabular}{|c|c|}
\hline & $\mathrm{DD}=\left(\mathrm{FIR} * \mathrm{C}_{\mathrm{i}}{ }^{*} \mathrm{PD}_{\mathrm{i}}{ }^{*} A V_{C i} * P T_{i} * F D R_{i}\right) / \mathrm{BW}$ \\
\hline $\mathrm{DD}$ & Daily Dose (mg DRC-1339 / kg BW / day) \\
\hline FIR & Food intake rate ( $\mathrm{g} /$ day) \\
\hline $\mathrm{C}_{\mathrm{i}}$ & Concentration of DRC-1339 in food type i ( $\mathrm{mg} / \mathrm{kg}$ wet weight) \\
\hline $\mathrm{PD}_{\mathrm{i}}$ & Proportion of food type $\mathrm{i}$ in the diet \\
\hline$A V_{C i}$ & Avoidance Factor of food type $i$ at DRC-1339 concentration C \\
\hline$P T_{i}$ & Proportion of food type $i$ obtained in the treated field \\
\hline$F D R_{i}$ & Fresh to dry weight ratio for food type $i$ \\
\hline BW & Body weight (g) \\
\hline
\end{tabular}

Note: $A V, P T$ and $F D R$ are italicized because they are assumed to equal 1 .

percent of the species utilizing the affected environment. This consists of the $5^{\text {th }}$ percentile of the log-normal distribution of the $\mathrm{LD}_{50}$ values. Additionally, to account for the uncertainty around this estimate, ECOFRAM has recommended using the one-sided 95\% confidence around the $5^{\text {th }}$ percentile. The ECOFRAM document proposed two methods for determining the $5^{\text {th }}$ percentile when only a few toxicity values are available. Both methods incorporate extrapolation factors. Because there are 40 avian median lethal dose estimates for DRC-1339, this assessment calculated the $5^{\text {th }}$ percentile directly instead of using an extrapolation factor. Additionally, no extrapolation factor was used to calculate the $5^{\text {th }}$ percentile for mammals.

When calculating the $5^{\text {th }}$ percentile of species sensitivity, we assumed the toxicity data for both birds and mammals have a log normal distribution. We also assumed a mean $\mathrm{LD}_{50}$ value when more than one $\mathrm{LD}_{50}$ was reported for a species, and $\mathrm{LD}_{50}$ estimates reported as $>$ or $<$ were eliminated from the calculation. DRC-1339 concentrations were assumed to be homogenous at a concentration of $769 \mathrm{mg} / \mathrm{kg}$ rice. No allowance was given for the probability that animals could select between treated vs. untreated rice grains. An animal's food intake rate (FIR) was calculated for passerine birds, nonpasserine birds and rodents using Nagy's weight-based allometric equations (25). Finally, because the dietary dose equation accounts for some of the uncertainty in the assessment, the RQ will be compared to a LOC of 1.0

First Level of Refinement

The first level of refinement utilized the same basic data used in the screening level assessment. However, actual body weights obtained from Dunning (26) and acute toxicity information for species found in the sunflower growing region were substituted for generic body weights and the $5^{\text {th }}$ percentile. Mammalian body weights were obtained 
Table II. U. S. EPA standard risk assessment results for granular bait

\begin{tabular}{lccc}
\hline Species & $L D_{s 0}(\mathrm{mg} / \mathrm{kg})$ & Body Wt. $(g)$ & $L D_{s o} / f^{2}(R Q)$ \\
\hline Red-winged blackbird & 2.4 & 53 & $3.15^{* * *}$ \\
Northern bobwhite & 2.6 & 178 & $0.87^{* * *}$ \\
Mallard & 100 & 1082 & $<0.01$ \\
Lab rat & 326 & 300 & $<0.01$ \\
Lab mouse & 960 & 30 & 0.01 \\
\hline
\end{tabular}

*** Exceeds the Acute High Risk LOC

from the DRC-1339 Reregistration Eligibility Decision (7). Because the dietary dose equation accounts for some of the uncertainty inherent in the assessment, the RQs generated by this method were compared to a LOC of 1.0 .

Second Level of Refinement

The second level of refinement moved the risk assessment from deterministic risk quotients to probabilistic quotients by expanding parameter estimates from point estimates to distributions by performing Monte Carlo sampling of equation parameters for which distributions of data were available. This was conducted using the risk analysis software @Risk (27). Food intake rates (FIR) were still based upon Nagy's allometric equations, however, body weight estimates were randomly selected from either truncated normal or normal distributions. Given that an average rice grain weighs $20 \mathrm{mg}$, the total number of grains per day was determined given FIR for a species. Percent of the diet that is treated (PD) was set as the ratio of 1 treated to 25 untreated rice grains or 0.038 . To determine the total number of treated rice grains consumed during a day, PD was multiplied by values drawn randomly from a binomial distribution based upon the total number of grains consumed per day and the probability of selecting a treated grain. Since the rice bait is formulated to yield $0.4 \mathrm{mg}$ per treated rice grain, the Daily Dose (DD) was determined by multiplying the total number of treated grains per day by $0.4 \mathrm{mg}$. Risk quotients were then calculated by dividing $\mathrm{DD}$ by the $\mathrm{LD}_{50}$ which had been normalized for the body weight of any given animal (mg DRC-1339/animal).

\section{Results}

Results of the current U.S. EPA $L D_{50} / \mathrm{ft}^{2}$ screening assessment, indicate that there is concern for some species of birds with respect to the DRC-1339 blackbird baiting program (Table II). High risk is predicted for the northern bobwhite (Colinus virginianus), and the red-winged blackbird (Agelaius phoeniceus), the target species. However, the risk to the mallard (Anas platyrhynchos) and mammals is so low the LOC for endangered species $(0.1)$ is not triggered.
Table III. Quotient based screening assessment using generic species data and the median concentration hazardous to $5 \%$ of species $\left(5^{\text {th }}\right.$ percentile).

\begin{tabular}{lcccc}
\hline Species & $\begin{array}{c}F I R \\
(g / \text { day })\end{array}$ & $\begin{array}{c}D D \\
(\mathrm{mg} / \text { day })\end{array}$ & $\begin{array}{c}5^{\text {th }} \text { percentile } \\
(\mathrm{mg} / \mathrm{kg})\end{array}$ & Risk Quotient \\
\hline 1000g Bird & 53.9 & 41.5 & 0.62 & $67^{*}$ \\
150g Bird & 12.9 & 66.5 & 0.62 & $107^{*}$ \\
30g Bird & 7.1 & 183.8 & 0.62 & $296^{*}$ \\
300g Mammal & 15.4 & 39.7 & 68.6 & 0.58 \\
30g Mammal & 4.2 & 108.4 & 68.6 & $1.56^{*}$ \\
\hline
\end{tabular}

Note: DRC-1339 concentration on rice is homogenous at $769 \mathrm{mg} / \mathrm{kg}$.

* Exceeds the Acute Risk LOC of 1.0.

The screening assessment based upon the ECOFRAM dietary dose equation indicate significant risk to all classes of animals, except larger mammals. (Table III). The $5^{\text {th }}$ percentile for birds and mammals is 0.62 and $68.6 \mathrm{mg} / \mathrm{kg}$, respectively. Clearly, the results of this screen indicate significant risk to all classes and weights of animals at the $5^{\text {th }}$ percentile of species protection level. These results indicate further refinement of the assessment is necessary to determine what environmental impacts are most likely and what types of mitigation measures should be considered to reduce those impacts to acceptable levels.

The second level of refinement in this assessment uses point estimate data for model inputs but incorporats site-specific information to represent species most likely to be found at the application site (Table IV). The surrogate species used in Table IV are not necessarily representative of similar sensitivity to DRC-1339, but are more representative of body weight and dietary parameters. For example, the red-winged blackbird is used as a surrogate for other Icterids such as the western meadowlark (Sturnella neglecta). It is not necessarily representative of the toxicological sensitivity of all Icterids. The sensitivity of the meadowlark is unknown and it cannot be assumed to be the same as the red-winged blackbird. However, given the large data set for the acute toxicity of DRC-1339, and the narrow range of sensitivities among the five Icterids tested, it in not unreasonable to assume the red-winged blackbird is representative of all Icterids. This is not the case for the mallard which is used to represent the body size and foraging patterns of other waterfowl. Because, the range of sensitivity to DRC-1339 for waterfowl (Family Anatidae) ranges from 20 to $100 \mathrm{mg} / \mathrm{kg}$, the uncertainty is to large to say the mallard is representative of the sensitivity of all waterfowl. The house sparrow (Passer domesticus) is considered a surrogate for other small granivorous species such as sparrows and finches. While the magnitude of the predicted hazard is significantly lower, the basic trend is the same, with acute high risk 
Table IV. Refined deterministic assessment using species specific data. DRC1339 concentration on rice is considered homogenous at $769 \mathrm{mg} / \mathrm{kg}$ rice

\begin{tabular}{lccccc}
\hline Species & $\begin{array}{c}\text { Weight } \\
(\mathrm{g})\end{array}$ & $\begin{array}{c}F I R \\
(\mathrm{~g} / \text { day })\end{array}$ & $\begin{array}{c}\text { DD } \\
(\mathrm{mg} / \text { day })\end{array}$ & $\begin{array}{c}L D_{50} \\
(\mathrm{mg} / \mathrm{kg})\end{array}$ & $\begin{array}{c}\text { Risk } \\
\text { Quotient }\end{array}$ \\
\hline Red-winged blackbird & 53 & 11.6 & 168.7 & 2.4 & $70.3^{*}$ \\
Northern bobwhite & 178 & 14.8 & 63.7 & 2.6 & $24.5^{*}$ \\
Ring-necked pheasant & 1135 & 59.2 & 40.1 & 10 & $4.0^{*}$ \\
Mourning dove & 119 & 10.9 & 70.4 & 5.4 & $13.0^{*}$ \\
House sparrow & 28 & 6.8 & 185.7 & 316 & 0.59 \\
Mallard & 1082 & 54 & 40.6 & 103 & 0.39 \\
Lab rat & 300 & 15.5 & 39.7 & 915 & 0.04 \\
Lab mouse & 30 & 4.2 & 108.4 & 960 & 0.11 \\
Deer mouse & 20 & 3.4 & 129.4 & 1800 & 0.07 \\
\hline
\end{tabular}

* Exceeds the acute risk LOC of 1.0

anticipated for most species of birds and lower hazard to mammals. Compared to the RQs calculated by $L_{50} / \mathrm{ft}^{2}$ methodology, hazard predictions for the birds and mammals have increased and now raise concern for restricted use and endangered species, respectively.

The results of the second level of refinement which employed probabilistic methods (Table V) yield roughly the same risk quotient patterns as those shown in the previous table. Significant hazard still is indicated for the red-winged blackbird, northern bobwhite, ring-necked pheasant (Phasianus colchicus) and mourning dove (Zenaida macroura). Little hazard is indicated for the house sparrow, mallard and mammals. The advantage of conducting a probabilistic assessment is that a distribution of hazard quotients is generated and the probability of a risk quotient exceeding the LOC can be determined by inspecting this distribution. For example, the house sparrow risk quotient is 0.6 with a range from 0 to 1.3 . The probability a risk quotient exceeds 1.0 for the house sparrow is $<5 \%(95$ percentile $R Q=0.85)$.

\section{Discussion}

\section{Model Comparison}

We conducted hazard assessments using two methods: the current methodology used by the EPA based upon $\mathrm{LD}_{50} \mathrm{~s} / \mathrm{ft}^{2}$ and methodology proposed by the EPA ECOFRAM workgroup. Both assessments focused on the primary hazards associated with birds and

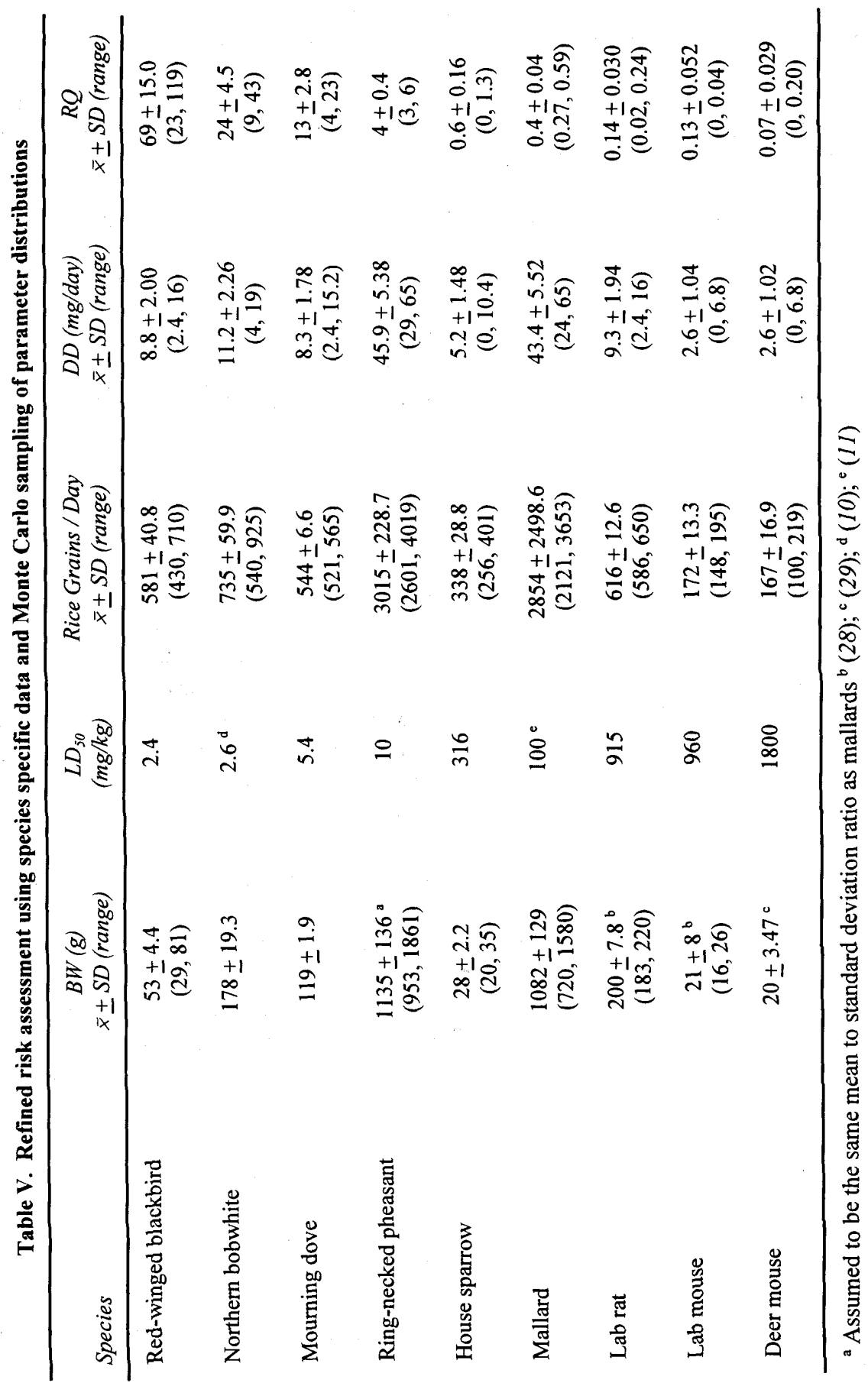


Table VI. Birds observed on or in the vicinity of DRC-1339 bait sites in North Dakota and South Dakota

\begin{tabular}{lc}
\hline Species & $\begin{array}{c}\text { Frequency of } \\
\text { observation (\%) }\end{array}$ \\
\hline American tree sparrow, western meadowlark; & $21-25$ \\
American coot, killdeer, Lapland longspur & $16-20$ \\
Canada Goose, mallard, vesper sparrow, song sparrow & $6-10$ \\
$\begin{array}{l}\text { American robin, ring-necked pheasant, horned lark } \\
\text { mourning dove, rock dove }\end{array}$ & $1-5$ \\
\hline
\end{tabular}
Note: Percentages are representative of the total number of counting periods during which a species was observed

mammals consuming DRC-1339-treated rice. The assessments assumed acute exposure resulting from an animal's entire daily dietary requirement consisting of brown rice obtained from the treated bait plots and did not consider other routes of exposure.

Both assessment methods identified the same basic patterns among species: hazard to mammals and mallards were low, hazards to other bird species were significant but variable. Both methods correctly identified the red-winged blackbird, a target species, as a species at high risk. While simple to use, the $\mathrm{LD}_{50} \mathrm{~s} / \mathrm{ft}^{2}$ method is extremely limited in the amount of refinement that can be done with the model. On the other hand, the dietary dose equation provides a single equation for exposure that can be easily refined to include site- and species-specific information, thus allowing the assessment to be easily adapted to address specific objectives. The primary limitation with the dietary dose equation is the availability of data.

Neither assessment method adequately predicts potential hazards for compounds like DRC-1339 that exhibit two modes of action, do not bioaccumulate, and are rapidly metabolized or eliminated from the body. To address these issues, factors for depuration and elimination rates would need to be included in the model. The hazard associated with single feeding (gorge feeding) bouts can be estimated using the dietary equation which is useful for fast acting compounds like organophosphates or carbamates. Without specific information on dietary intake, the assessment is conservative in that the total daily intake is related to the $\mathrm{LD}_{50}$ and no allowance is made for subacute exposure extended throughout a day. The assessment can be used for more than a screen if specific foraging information is input to the equation for FIR.

The conservative nature of this assessment can be demonstrated by substituting estimates of the daily food intake rate other than that recommended by Nagy. Kendeigh (30) calculated existence metabolism requirements ( $\mathrm{kcal} / \mathrm{bird}$-day) regression equations for both passerine and non-passerine birds. The majority of the 13 passerine species were sparrow sized granivores. The five non-passerine species included 3 pheasant species, the Canada goose and mallard. Using Kendeigh's allometric equations and a value of $360 \mathrm{cal} / 100 \mathrm{~g}$ uncooked brown rice (31) daily food intake estimates in terms of number of rice grains per day are approximately $50 \%$ lower than those estimated by Nagy's method and shown in Table V. Risk quotients based upon this estimate would be approximately 50\% lower and still show the same trend; no concern for house sparrows and mallards, while RQs for the red-winged blackbird, northern bobwhite, mourning dove, and ring-necked pheasant still exceed the LOC of 1.0.

Field data from Cummings et al. (32) also can be used to illustrate the conservative nature of the assessment by illustrating the effect FIR has on the outcome. Cummings collected 118 red-winged blackbirds as they left bait plots in Louisiana. He reported that the median number of rice grains in the GI tract of these birds was 28 and ranged from 0 to 83 . Considering the red-winged blackbirds contained a maximum of 83 and a median of 20 grains of rice, the RQ for a single feeding bout would be reduced to approximately 10 or 3.3 respectively. Single foraging bout data for other species of concern would undoubtedly lower their respective risk quotients.

\section{Risk Characterization for Nontarget Species}

Concern has been expressed for all nontarget species in the treatment area. However, the major emphasis has been on the western meadowlark and ring-necked pheasant, and sparrows. To identify the species most at risk in the northern Great Plains, Knutsen (33) conducted avian censuses during 2 consecutive years in cornfields during spring blackbird baiting. Employing point-count and video monitoring census methodology, Knutsen observed 774 individual birds, representing 31 species, either at or in the area of bait plots. Twenty-six of these species were nontarget species. Fourteen species observed during at least one percent of the observation periods (Table VI).

Two years prior to Knutsen, Kenyon (34) conducted avian surveys around bait sites in South Dakota. Fifty-seven, 15-minute point-count surveys were done at sites baited with untreated brown rice. No nontarget birds were observed during $(52 \%)$ of the pointcounts. A total of 476 nontarget birds ( 20 species) were observed in the remaining $(48 \%)$ of the observation periods. Ring-necked pheasants, western meadowlarks, and waterfowl (mallard, Canada goose, and green-winged teal) were observed in less than $10 \%$ of the point-counts. Insectivorous birds (American robin, northern flicker, downy woodpecker, and killdeer) as a group were observed during nearly $30 \%$ of the pointcounts. Granivores (American tree sparrow, song sparrow, clay-colored sparrow, darkeyed junco, horned lark, and mourning dove) as a group were observed in approximately $(21 \%)$ of the point-counts.

Comparison of the species list derived from these two studies to the refined risk assessment results identifies species of highest concern. While not conclusive, it appears that there is some basis for assuming a taxonomic-based grouping for species sensitivity to DRC-1339. The western meadowlark belongs to the family Icteridae. All species tested in this family are highly sensitive to DRC-1339 $\left(\mathrm{LD}_{50} \leq 10 \mathrm{mg} / \mathrm{kg}\right)$. Because they are roughly the same size as a blackbird and are assumed to be equally sensitive to DRC-1339, risk quotients and the probability of survival would likely be 
similar. During the spring, the meadowlark's diet is $80 \%$ invertebrates and $20 \%$ seeds gleaned from the ground (35). However, when invertebrates are scarce, plant material can comprise a substantial portion of their diet.

The mean RQ for the ring-necked pheasant is 4 , therefore, acute risk is indicated. In the dietary dose model, pheasants are predicted to consume more than 3000 rice grains (115 treated grains) per day. Because of the sheer volume of seeds a large bird can eat, it is likely it will eat more treated rice grains than smaller birds. Given the relatively high sensitivity of the ring-necked pheasant to DRC-1339 $(10 \mathrm{mg} / \mathrm{kg})$ an adult bird need eat only 28 treated grains, or 750 total grains, at one feeding to ingest a dose equal to the $\mathrm{LD}_{50}$. At $20 \mathrm{mg}$ per grain of rice, 750 grains of rice equals $3.75 \mathrm{~g}$ of rice. While reasonable to assume a ring-necked pheasant can consume $3.75 \mathrm{~g}$ of food during one feeding bout, field observations show that pheasants move rapidly through baited plots and are unlikely to take a sufficient rice grains to cause acute effects (33). Further, Avery et al. (36) speculated that there may be some learned aversion to treated bait sites by demonstrating that in large enclosure trials at least some pheasants do not return to food sites where they previously ate DRC-1339-treated rice. Additionally, they found female pheasants preferred cracked corn and sorghum over brown rice.

The northern bobwhite, with a $\mathrm{LD}_{50}$ of $2.4 \mathrm{mg} / \mathrm{kg}$, is sensitive to DRC-1339. The risk quotients for this species is approximately 24 , indicating a high potential for acute effects if they consume treated rice. The northern bobwhite is not found in the northern Great Plains, however, the results for the bobwhite could be considered an indicator for other Phasianids for which there is no acute toxicity data available. During the four years Kuntsen (33) and Kenyon (34) conducted observations, excluding the ring-necked pheasant, only one other Phasianid, a single gray partridge (Perdix perdix), was observed in the baited sites.

Sparrows and longspurs are frequently observed at or around bait sites. Despite this, the risk to these species appears to be low, given the relative insensitivity of the Emberizidae and Fringillidae $\left(\mathrm{LD}_{50} \mathrm{~s} 100\right.$ to $\left.400 \mathrm{mg} / \mathrm{kg}\right)$. Cummings et al. (32) examined the risk to sparrows using three methods. Thirteen savannah sparrows were collected as they left bait sites baited with untreated brown rice. Upon inspection of the gastrointestinal tract, only one sparrow contained rice and only one grain was found in this bird. In a separate effort, 20 sparrows ( 9 savanna, 8 white-crowned, and 3 field sparrows) were live trapped at bait sites baited with DRC-1339-treated brown rice. Only two savannah sparrows died during the 10-day holding period. These deaths were attributed to capture related injuries. Finally, 72 sparrows ( 54 savanna, 9 white-crowned, 3 song, and 3 field sparrows) were live trapped in untreated fields. After acclimating to cages, they were denied food overnight (12 hours) and provided DRC-1339 treated brown rice for a 12-hour period. No sparrows died during the 5-day post-treatment observation period.

The studies reported by Cummings et al. (32) were conducted during spring baiting in Louisiana. The availability of alternative foods and other environmental factors are undoubtedly different from those found during spring baiting in North Dakota and South Dakota. These differences could certainly affect the dietary preferences of sparrows. However, the results do provide evidence that brown rice treated with DRC-1339 is not a preferred food for sparrows, even under the severe conditions of a single choice test following a starvation period. These results support the dietary dose equations of low risk and the probability that risk to sparrows under operational use is low.

As reported by Knutsen (33), mourning doves (Zenaida macroura) and rock doves (Columba liva) were found on 1-5\% of all observed bait sites. As indicated in Figure 1, the $\mathrm{LD}_{50} \mathrm{~s}$ of the 5 species tested in the family Columbidae ranged from $8 \mathrm{mg} / \mathrm{kg}$ to 20 $\mathrm{mg} / \mathrm{kg}$. Under the conditions of the dietary dose equation, significant risk is predicted for the mourning dove and Columbids. The food intake model predicts an average daily intake of 544 grains of rice, with an average hazard quotient of 13. Consumption of 42 rice grains ( 2 treated grains) during a single feeding bout would be approximately equivalent to the mourning dove $\mathrm{LD}_{50}$. Thus, doves feeding on the treated rice bait are at high risk of acute exposure.

The susceptibility of the horned lark (Eremophila alpestris), a predominantly granivorous species (35), is unknown. No toxicity data are available for this species or other members of their taxonomic family. If one is conservative and assumes these birds are as sensitive as the most sensitive species or even as sensitive as the calculated $5^{\text {th }}$ percentile, significant risk is indicated. Although the American robin (Turdus migratorius $)$ is sensitive to DRC-1339 $\left(\mathrm{LD}_{50}=3.2 \mathrm{mg} / \mathrm{kg}\right)$, the risk to this species may be low because they feed primarily on fruit and invertebrates during the spring and they were present on less than $5 \%$ of the bait sites observed by Knutsen. The killdeer (Charadrius vociferus) was found in $15 \%$ to $20 \%$ of Knutsen's observation periods. The sensitivity of the killdeer to DRC-1339 is unknown, however, the risk to this species may be low because it's diet is predominantly animal material (35) and the probability it will consume rice is low.

Finally, both risk assessment methods identified mammals as at little risk from the baiting program. With the exception of cats, the mammals tested for acute toxicity are not sensitive to the effects of DRC-1339. Cats are unlikely to eat uncooked rice so the risk of primary exposure is low.

The spring blackbird baiting program presents a potential hazard to some nontarget species, if they eat the DRC-1339-treated rice bait. However, to reduce nontarget hazards, mitigation measures have been incorporated into the baiting operations. First, the spring baiting program is conducted prior to the arrival of most spring migrants (Linz, G.M. USDA National Wildlife Research Center, Bismarck, ND, pers. comm. 1999). Prebaiting is conducted to habituate target birds to feeding at a particular site and to feeding on brown rice. Prebaiting also provides an opportunity to observe nontarget activity on the bait site and to change bait locations if necessary. Brown rice is used exclusively as the bait material. Blackbirds readily accept brown rice while some nontarget species prefer other more familiar foods (37). The bait is always diluted at a ratio of at least 1 part treated rice to 25 parts untreated rice, which significantly reduces the probability a bird will pick up a treated grain. This is especially important for small birds which consume only a few grains during a foraging bout. Finally, caged decoy blackbirds often attract large flocks of blackbirds which may deter nontarget species from feeding on bait sites (Allen, A.E. USDA Wildlife Services, Crowley, LA, pers. comm. 1999) 


\section{Acknowledgments}

We would like to thank David Fischer for his help with developing the probabilistic model, and Michael Avery, John Cummings, Robert Troup, Ed Schafer, Kathy Fagerstone, Mark Tobin, Alain Baril and Brett Petersen for their technical review.

\section{Literature Cited}

1. Homan, H.J.; G.M. Linz; W.J. Bleier, Am. Mid. Nat. 1994 131:381-385.

2. Twedt, D.J., W.J. Bleier, and G.M. Linz, 1991, Condor. 93:975-986.

3. Lilleboe, D. The Sunflower. 1996, 22:10-13.

4. Linz, G.M.; Bergman, D. L, Crop Protection. 1996, 15:307-310.

5. U.S. Environmental Protection Agency. Ecological Committee on FIFRA Risk Assessment Methods Terrestrial Draft Report. 1999, May 10, 1999.

6. U.S. Department of Agriculture, Animal Damage Control: Final Environmental Impact Statement. 1994. Vol. 3, pp194-202.

7. U.S. Environmental Protection Agency. Reregistration Eligibility Decision (RED): Starlicide (3-chloro-p-toluidine hydrochloride). 1995, EPA-738-R-96003.

8. Schafer, E.W.; W.A. Bowles; J. Hurlbut, 1983, Arch. Environ. Contam. Toxicol. 12:355-382.

9. DeCino, T.J.; D.J. Cunningham,; E.W. Schafer, J. Wildl. Manage. 1966. 30:249253.

10. Fletcher, D.; C. Pedersen, Final Report. Lab Project No. BLAL \# 89 DD 71; 1990 , Bio-Life Associates, Ltd., Neillsville, WI.

11. Fletcher, D.; C. Pedersen, Final Report. Lab Project No. BLAL \# 89 DD 135; 1990 , Bio-Life Associates, Ltd., Neillsville, WI.

12. Peoples, S.A. Progress Report on Starling Control to the Denver Wildlife Research Center, Univ. Calif.-Davis, CA, 1965.

13. Schafer, E.W.; W.A. Bowles. Arch. Environ. Contam. Toxicol. 1985, 14:111-129.

14. Schafer, E.W. Toxicol. Appl. Pharm. 1972, 21:315-330.

15. Apostolou, A. PhD. Dissertation. University of California at Davis, 1969.

16. Apostolou, A.; Peoples, S. A. Toxicol. Appl. Pharmacol. 1971, 18:517-521.

17. Mull, R.L. Ph.D. Dissertation. University of California at Davis, 1971

18. Giri, S.N.; D.E. Gribble; S.A. Peoples. 1976, Fed. Proc. 1976. 35:328.

19. Borison, H.L.; S.R. Snow; D.S. Longnecker; R.P. Smith. 1975. Toxicol. Appl. Pharma. 31:403-412.

20. Felenstein, W.C.; R.P. Smith; R.E. Gossein, 1974. Toxicol. Appl. Pharm. 28:110125.

21. Palmore, W.P. Florida Veterinary Journal. 1978.

22. Giri, S.N.; D.M. Siegel; S.A. Peoples. 1978, Toxicol. 11:153-165.

23. Urban, D.J.; Cook, N.J. Standard Evaluation Procedure for Ecological Risk Assessment. 1986, EPA/540/09-86/167.
24. Pastorok, R.A.; M.K. Butcher; R.D. Nelson. Human and Ecological Risk Assessment. 1996, 2:444-480.

25. Nagy, K.A. 1987, 57:111-128

26. Dunning, J.B. CRC Handbook of Avian Body Mass; CRC Press, Boca Raton, FL, 1993.

27. Palisade Corp. @RISK: Advanced risk analysis for spreadsheets. Version 3.5.2. 1997, Newfield, NY.

28. McCann, G.M.; G.H. Matschke. Final Report, QA-506, National Wildlife Research Center, Fort Collins, CO.

29. U.S. Environmental Protection Agency. EPA/600/R-93/187a, 1993.

30. Kendeigh, S.C. The Condor. 72:60-65.

31. Altman, P.L. and D.S. Dittmer. Metabolism; Fed. of Amer. Soc. for Exper. Biol. Bethesda, MD, 1968.

32. Cummings, J.L.; J.F. Glahn; E.A. Wilson; J.E. Davis; D.L. Bergman; G.A. Harper Final Report. Bird Section Research Report No. 481, Denver Wildlife Research Center, Denver, CO, 1992.

33. Knutsen, G.A. M.S. Thesis. North Dakota State Univ. Fargo, ND, 1998.

34. Kenyon, M.J. MS Thesis. North Dakota State Univ. Fargo, ND, 1996.

35. Martin, A.C.; H.S. Zim; A.L. Nelson, American Wildlife and Plants: A guide to wildlife food habits. Dover Pub., New York, 1951.

36. Avery, M. L.; M. J. Kenyon; G. M. Linz; D. L. Bergman; D. G. Decker; J. S. Humphrey. J. Wildl. Manage. 1998, 62:388-394.

37. Linz, G.M.; H.J. Homan; R.L. Wimberly; G.A. Knutsen. In Pesticides \& Wildlife, Johnston, J.J. Ed.; ACS Symposium Series, American Chemical Society: Washington, DC, in press. 